\title{
Recent trends in reproductive tourism and international surrogacy: ethical considerations and challenges for policy
}

This article was published in the following Dove Press journal:

Risk Management and Healthcare Policy

17 August 2015

Number of times this article has been viewed

\section{Raywat Deonandan}

Interdisciplinary School of Health Sciences, University of Ottawa, Ottawa, ON, Canada
Correspondence: Raywat Deonandan Interdisciplinary School of Health Sciences, University of Ottawa, 25 University Private - THN-208, Ottawa, ON KIN 6N5, Canada $\mathrm{Tel}+$ I 6135626800 ext 8377 Email raywat.deonandan@uottawa.ca
Abstract: Reproductive tourism, or "cross-border reproductive care", is the phenomenon of people crossing international borders to access reproductive technologies. One of the fastest-growing categories of cross-border reproductive care is international surrogacy, the act of infertile clients traveling internationally to engage the paid services of foreign surrogates to carry their babies to term. It is a multibillion-dollar global industry presenting unique legal, ethical, and risk-management challenges. Clients tend to be price-sensitive, middle-income individuals seeking services from surrogates who in the global market are thought to be of quite low socioeconomic status. Risks are experienced by all parties involved in the transaction, including the client's countries of origin and destination. The risks to the surrogate evolve from the potential to exploit her economic vulnerability in order to encourage both consent and unfair pricing. Opportunities for policy development are explored.

Keywords: surrogacy, assisted reproduction, medical tourism, IVF, ART, gestation

\section{Introduction}

The global industry of commercial surrogacy - the phenomenon of women renting their wombs to clients for the purposes of creating babies - is estimated to be worth approximately \$US6 billion annually. ${ }^{1}$ When clients cross an international border to engage a paid surrogate, they are participating in the phenomenon of reproductive tourism, also called "fertility tourism", "cross-border reproductive care" (CBRC), or "reproductive exile".,3 The phenomenon describes any travel to seek commercially provided assisted reproductive technologies (ARTs), which can include in vitro fertilization, preimplantation genetic diagnosis, gamete procurement, or a host of other services. However, the hiring of surrogate mothers presents particular challenges with respect to risk management, ethics, and the building of regulatory frameworks.

In India, which is fast becoming the global champion in providing commercial ART, surrogacy may be worth approximately $\$ 400$ million annually, generated from the country's approximately 3,000 specialty clinics. ${ }^{4}$ The US is the other great provider of surrogates, with California and New Jersey leading the list of states that are home to surrogate births, each of which produce approximately 100 births per year. ${ }^{5}$ Anecdotal evidence suggests that Thailand, Ukraine, and Russia are other popular sources of surrogates for an international clientele, while Mexico, Nepal, Poland, and Georgia are quickly gaining similar reputations. ${ }^{6}$

Gestational surrogacy is distinct from traditional surrogacy in that the latter involves a pregnancy using the surrogate's own ova, often involving artificial insemination, whereas the former necessitates reliance upon reproductive technologies to create 
embryos in vitro using external sperm and ova, which are then incubated by the surrogate. The distinction of gestational surrogacy is that the surrogate is not genetically related to the child being produced, theoretically making a commercial transaction less legally and emotionally problematic.

International surrogacy has gained popularity in recent years, due both to the inconsistency of international restrictions and to advances in technology allowing for easier gestational surrogacy. ${ }^{7}$ Commercial surrogacy has been legal in India since 2002, but India's surrogacy boon began in January 2004 with a grandmother delivering her daughter's twins. ${ }^{8}$ While many Indian ART clinics are hesitant to advertise the fact that they offer surrogacy services to foreign clientele, an analysis of Indian clinics' websites concludes that "reproductive tourism comprises a substantial fraction of India's assisted reproduction technologies clinics' business focus, clustering around its most tourist-friendly locales, and surrogacy may be a strong motivator for international clientele". ?

Information on the extent of surrogacy, either within a specific country or transnationally, is scarce indeed. This is due to the absence of a robust international reporting system. In the US, only gestational surrogacy tends to be reported, with almost no data available about the distribution or popularity of traditional surrogacy. ${ }^{5}$ According to the Society for Assisted Reproductive Technologies, over 1,000 babies are born annually in the US via gestational surrogacy alone. ${ }^{5}$ Meanwhile, approximately $5 \%$ of all European fertility care likely involves cross-border travel. ${ }^{10}$

\section{Motivations and drivers}

Residents of wealthy nations are traveling to less wealthy ones in increasing numbers for the purposes of seeking medical care of all types. ${ }^{11}$ While the exact size of the medical tourist population is unknown, anecdotal evidence places it in the hundreds of thousands to several millions yearly. ${ }^{12}$ The number of those specifically seeking reproductive services globally is also unknown, but likely numbers in the tens of thousands in Europe alone ${ }^{13}$ and (again anecdotally) in the hundreds of thousands in Asia.

Generally, the need to travel to seek reproductive services is shaped by a combination of legal restrictions forcing people out of their home countries and attractive services drawing patients to foreign countries to access those services. ${ }^{14}$ The motivations for all types of medical tourism tend to be economics and availability in nature, meaning that lower costs of services abroad are an incentive, as is the opportunity to bypass either a service wait list or a domestic legal impediment to service. However, reasons for seeking cross-border care can be complex, and are dependent on the nature of the service sought. ${ }^{15} \mathrm{CBRC}$ seekers ("reproductive tourists"), therefore, may not resemble organ-transplant tourists or surgery tourists.

Medical tourists can be divided into two types: qualitysensitive and price-sensitive. The first type includes individuals who tend to be more affluent and are seeking better quality and more expensive care abroad. The second type tends to include those of the middle class who are seeking nonurgent procedures at reduced price. CBRC seekers are among the second type, though their motivation can transcend cost. Some nations, like Canada, forbid paid surrogacy. Therefore, for Canadians struggling to find an altruistic surrogate, travel to a more lenient jurisdiction becomes a prime motivator, regardless of cost.

Studies specifically exploring the motivations of CBRC seekers are few, but do reveal a nuanced pattern. A study in New Zealand ${ }^{16}$ reported that CBRC clients from that country were motivated by the limited availability of gamete donors in their home jurisdiction, difficulty in meeting treatmenteligibility criteria, and the fact that some treatments were legally prohibited at home.

The legal prohibitions that enable CBRC are of two types: restrictions on who can access fertility care, and restrictions on what fertility care can be..$^{10}$ Restrictions on patient age, marital status, and sexual orientation are legally prescribed in some countries, which can motivate older, single, and homosexual individuals to travel for services. "By contrast, in some US states, strict non-discrimination laws prohibit ART clinics from denying care on the basis of a host of demographic factors, including race, ethnicity, marital status, and sexual orientation". ${ }^{10}$

Despite being motivated by a variety of factors, all CBRC seekers share three major characteristics: the desire for a child who is genetically related to them, the inability to produce this child through natural means, and a willingness to expend significant resources to produce the child. ${ }^{17}$

The motivations and descriptions of surrogate mothers are less well studied. One scholar points out that "human body resources" are more available and affordable in lowincome countries, where "poor and vulnerable" populations are both available in large numbers and are perceived as being more willing than citizens of wealthier countries to jeopardize their personal health for minimal financial reward. ${ }^{11}$ It is thus speculated that the primary motivation of surrogates is financial, as Indian surrogates can make as much as $\$ 6,000^{18}$ (compared to a typical American surrogate, 
who would earn \$20,000), ${ }^{19}$ which is substantially more than they would earn otherwise, though it is possible that feelings of altruism are also involved. Indeed, there has been some anecdotal speculation that the participation of Indian surrogates is motivated or encouraged by a religious desire to help lift the "curse" of infertility from their clients. ${ }^{20}$

In fact, little is known about who the surrogate mothers in India are, as clinics are hesitant to share such data with researchers. However, there is some indication that they are likely poorly educated and of low social status. ${ }^{21}$

\section{Risks}

There are some well-explored public health risks associated with ART in general, including the potential role of gametes as disease vectors. ${ }^{22}$ Risks associated specifically with the gestational surrogacy industry are largely ethical, ${ }^{23}$ economic, financial, and legal in nature, and can be divided into seven categories: 1) risks to the source country (the state of origin of the $\mathrm{CBRC}$ client); 2) risks to the destination country; 3) risks to the CBRC seekers; 4) risks to the surrogate mothers; 5) risks to the clinics and clinicians performing the ART procedures; 6) risks to brokering parties, such as medical tourism promoters, insurance companies, nongovernmental organizations, and health care workers with a peripheral interest in the surrogacy industry; and 7) risks to the children produced through surrogacy. This review does not consider the needs and experiences of actors in categories 5 and 6, as they have not been adequately studied, nor do they yet represent a substantial stake relative to those of actors in the first four categories. Category 7 will not be explored here either, as research on both the short- and long-term impact on children produced through surrogacy is scarce indeed, and rarely evolves past speculative, as in the case of the microchimerism example described later in this paper.

\section{Risks to the source country}

Risks experienced by the country of origin of the CBRC traveler are either of a legal or economic nature. Also, to the extent that regulatory issues reflect societal values, elements of the source country's values system may also be affected.

Economically, one of the common arguments against any kind of medical tourism is that the traveler is spending his or her money in a foreign country rather than in their home jurisdiction. Their expenditure includes both payment for medical treatments and payment for services associated with travel. This is not an inconsequential amount, given the size and value of the industry, representing a loss of income opportunity for the source country.
Legally, if travelers are crossing borders to avoid restrictions in the source country, then that country's ability and willingness to enforce its restrictions comes into question. There are instances in which states choose to prosecute their citizens who commit acts that are illegal at home but perhaps legal in the jurisdiction in which the act occurred. Most commonly, these instances are of a highly distasteful nature, such as child sex tourism, eg, the US Protect Act, ${ }^{24}$ which allows for the legal prosecution of American citizens who purchase the sexual services of minors outside American soil.

It can be argued that the unwillingness of a state to enforce its statutes when citizens who violate them abroad return represents a tacit approval of the offending act. The fact that countries like Canada, where paid surrogacy is not permitted under the Assisted Human Reproduction Act, ${ }^{25}$ nevertheless has a process for the adoption and conferring of Canadian citizenship upon children created by paid surrogacy abroad suggests that there is a disconnection between the extent to which the nation's domestic law is assumed to reflect its society's values and the extent to which such values are expressed in the actual enforcement of that law.

\section{Risks to the destination country}

Much like the risks posed by international surrogacy to the CBRC client's source country, those experienced by the nation providing the reproductive services can be divided into three categories: financial, legal, and values-based. For a nation like India, which harbors a thriving and lucrative surrogacy industry, the financial benefits are substantial. However, it should be noted that while the medical expertise and resources were produced and paid for by Indian citizens, it is the foreign clientele that reap the rewards. This is one of the most common criticisms of all types of medical tourism: that a nation's taxpayers should be the ones who benefit from the attentions of doctors whose education and infrastructural support were taxpayer-subsidized.

While a nation's laws are ideally thought to mirror the values of its people, it is possible that a sufficiently powerful industry may influence those laws to reflect its needs instead. For example, Indian regulations hold that a gestational surrogate abandons all parental rights at the point of delivery, a rule that benefits the industry. In contrast, the US state of Michigan does not recognize surrogate contracts at all. ${ }^{26}$ The extent to which the Indian practice reflects the values of its citizenry rather than those of the industry is unclear.

Moreover, the rapid growth of the industry and its globalized nature necessarily introduce practices and values from different countries into a milieu that may be culturally 
unprepared for such rapid change. An example is the case of a conservative Indian village woman bearing a child for two foreign gay men. Same-sex family-building would likely be a novel experience for the surrogate's community. While it can be argued that such an experience is progressive and socially positive, it is nevertheless likely that its introduction was hastened by the presence of the reproductive tourism industry.

\section{Risks to the CBRC seekers}

People traveling internationally and spending large amounts of money to create their families are by their very nature vulnerable. They have typically struggled with biological infertility (or in the case of same-sex couples, social infertility) for many years, and have chosen the international surrogacy route after much travail. The threat is high for unsupported promises, by disreputable clinics and brokers, of high success rates, seamless legal procedures, uncomplicated surrogacy negotiations, and comfortable travel experiences.

As with all ART procedures, the commissioning couple risks creating a child with particular needs, as in the case of "baby Gammy" described herein. Most commonly, though, the risk is financial. As noted, CBRC seekers tend to be price-sensitive, and may be acquiring great debt on a venture whose outcome is not guaranteed.

\section{Risks to the surrogate mothers}

Risks to the surrogates can be of a social, legal, physical, or emotional type, and all can be placed somewhere on the continuum between respect for autonomy and exploitation of that autonomy. Acknowledging a woman's right to use her body as she chooses can be framed as a celebration of her autonomy. Her actions may be distasteful to some, but a Western liberal ethical framework would nonetheless underscore her right to express her informed consent to participate in a commercial transaction involving her body, whether that participation comes in the form of physical labor, sexual services, organ or tissue donation, or commercial surrogacy.

On the other hand, given that surrogates (in low-income countries like India) are thought to be largely economically disempowered, it is rational to argue that their autonomy is being expressed from a space of desperation and thus vulnerability. To benefit from such autonomy can be described as the exploitation of desperation. The risks to economically and educationally disadvantaged surrogates, then, arise from their vulnerability to exploitation.

Humbyrd argues that concern for surrogates' wellbeing can be divided into arguments about their welfare, commodification, and exploitation. The author further argues that "the only valid objection to international surrogacy is that surrogate mothers may be exploited by being given too little compensation", leading to the recommendation that pricing standards be enforced, as a kind of "fair trade surrogacy". ${ }^{27}$

The biological risks to surrogates are those shared by all pregnant women, and in the case of ART procedures, there is a heightened risks for multiple pregnancies, which are problematic for both the surrogate and fetuses. Physiological outcomes of pregnancy can range on the spectrum of seriousness from migraines and back pain at the low end to diabetes, high blood pressure, or permanently impaired fertility further along to death in extreme cases. The emotional risk faced by all surrogates is the potential emotional attachment to a child that she must give away immediately after delivery. Postpartum concerns include scarring and other physical consequences from cesarean sections, as well as postpartum depression.

Additionally, economically poor surrogates in countries like India face particular social risks, including potential disapproval from their communities and rejection by their husbands. These types of risks are rarely, if ever, expressed in the informed-consent discussion, and ethically should be raised if autonomy is to be truly respected.

\section{Legal pitfalls and the regulatory landscape}

How a nation conceptualizes its version of the relationship between commerce and reproduction ultimately reflects that nation's understanding of its own values. It also reflects the state's understanding of its role and responsibilities with respect to its people. ${ }^{28}$ The framing of laws on surrogacy simultaneously shapes the evolution of the surrogacy industry, and the laws themselves are shaped by that same industry. A nation with laws disfavoring the surrogate and favoring the client is a more attractive destination for a reproductive tourist seeking the fewest legal barriers. ${ }^{23}$ For example, Michigan's Surrogate Parenting $\operatorname{Act}^{26}$ does not allow for recognition of surrogate-parentage contracts, meaning that the surrogate has strong rights regarding potential custody. Meanwhile, Indian law is robust in recognizing the legality of the surrogate contract, ${ }^{29}$ thus providing more assurance for the client. Regulatory approaches must therefore dance upon the thin line between satisfying the public's moral hesitation and empowering a potentially lucrative industry.

Guidance on establishing a nation's legal narrative with respect to surrogacy, for signatory nations, must conform to the United Nations Convention on the Rights of the Child and the Hague Convention on the Protection of Children and Co-operation in Respect of Intercountry Adoption, both of 
which are focused on the fundamental rights of children and the obligation to prevent the abduction, sale, or trafficking of children.

Even with such guidance, the global regulatory framework is heterogeneous, with many nations having no federal statures at all. With respect to the key Western nations thought to be providing the bulk of clientele for international surrogacy (the US, Australia, Canada, New Zealand, Israel, and the UK), all except the US have a federal regulatory presence and distinguish between gestational and traditional surrogacy and between paid and unpaid surrogacy, with most choosing to criminalize the former but not the latter. ${ }^{30}$ Policies concerning the repatriation of children produced by ART abroad vary widely, with some nations requiring the commissioning parents to legally adopt the produced child, even if that child is a genetic relative. One interpretation is that babies born to commercial gestational surrogates are stateless until adopted, meaning that simply being born in a country does not automatically confer citizenship of that country, thus freeing that state from much of the obligation to care for the child.

Israel was the first country to implement state-controlled surrogacy, wherein every surrogacy contract must be individually approved by the government; ${ }^{31}$ under the "embryo carrying agreements law", surrogates must be single, widowed, or divorced. In Georgia, surrogacy is legal, but the rules strictly prohibit surrogates from exercising any rights over the child. ${ }^{32}$ Some countries, like Russia, require that there be a medical reason for surrogacy. ${ }^{33}$

In Japan, surrogacy is banned outright. In fact, doctors, agents, and clients can be punished for commercial surrogacy arrangements. ${ }^{34}$ Clearly, this prohibition does not extend to Japanese citizens traveling abroad for surrogacy services, as in the case of "baby Manjhi" described herein. The perception that surrogacy is fraught with biological risk may be driving Japanese society's disapproval of the practice. ${ }^{35}$

Meanwhile, in the People's Republic of China, surrogacy was banned in 2001, though there are reports of a thriving underground black market for surrogacy services. ${ }^{32}$ The Chinese approach is not surprising, given that country's history of promoting policies to limit population growth.

In Saudi Arabia, religious authorities do not allow the use of surrogates, ${ }^{34}$ which is to do with their interpretation of Koranic law. The role of surrogacy in Islamic cultures is a well-debated issue. In the majority Sunni interpretation, the participation of a third party to create a child is seen as a kind of adultery, ${ }^{36}$ whereas in Shiite interpretation, surrogacy is permitted with the caveat that the sperm donor must be recognized as the true father. ${ }^{37}$
India and Thailand are two of the few countries in the world where surrogacy does not exist in a legal desert; rather, it is overtly legal, up until 2015. In early 2015, however, Thailand made international news by overtly banning commercial surrogacy for foreigners ${ }^{38}$ after a particularly problematic case involving an abandoned baby ("baby Gammy", described herein) that had been commissioned by an Australian couple. ${ }^{39}$

In India, meanwhile, while lawmakers have not yet made new law on the specific circumstances and requirements of either surrogacy or its related reproductive services and technologies, their most recent draft bill (2013) is a departure from the previous bill. ${ }^{40}$ It indicates that their focus is on clinical matters, and not on the restriction or limitation on the scope or complement of service provision, a tack which is unlikely to diminish the flow of foreign clientele to Indian ART clinics. Activist groups accuse the government of structuring its bill to best service ART commercial interests and not sufficiently protecting Indian surrogates or properly reflecting the true sentiment or values of the electorate. ${ }^{41}$ On its face, the bill exists to protect the rights and welfare of all players in the ART industry. However, its focus appears to be the avoidance of legal disputes over parentage for the purposes of easing international adoption procedures and thus lubricating the industry as a whole. ${ }^{42}$

Policy discussions pertinent to India's evolving regulatory frameworks tend to settle on a few constants. Among these are: no ART procedure should be performed without the client's spouse's consent; sex selection cannot be permitted except to prevent sex-based disease transmission; the surrogate should be a stranger to the commissioning couple; it should be prohibited to sell embryos and gametes outside of the country; it is preferable that the commissioning client(s) be a married couple; the surrogate should relinquish all parental rights over the child; it is highly desirable that the sperm originate only from either the male member of the commissioning couple or from an official sperm bank; ${ }^{8}$ and donations from male acquaintances are seen as an unnecessary complication.

What remains to be seen is how India's eventual law will consider same-sex parents, as reports famously suggest that a strong preference is being expressed for heterosexual parentage alone..$^{43}$ There is further uncertainty about whether age limits will be placed on surrogates, whether minimum compensation levels will be legislated, and whether additional criteria (beyond heterosexuality) will be required of the commissioning foreign clients. ${ }^{44}$

From the perspective of those seeking to make the Indian surrogacy business less legally complicated (though not 
necessarily more ethical), additional desirable elements to any comprehensive bill include that: the specifics of any surrogacy arrangement should be governed by the text of the surrogacy contract signed by both the surrogate and the commissioning parent, which should be recognized in a court of law; the privacy of gamete donors must be protected; the birth certificate of the produced child shall only indicate the commissioning parents' names, and not that of the surrogate; and that surrogacy contracts should include life insurance coverage in case of the death of the surrogate. ${ }^{8}$

Attempts at legal harmonization in other parts of the world are focused on safety and quality standards. In Europe, this is driven by Directive 2004/23/EC, which outlines quality standards for human tissues and cells. ${ }^{45}$ Factors that all frameworks must consider include: whether babies born from commercial surrogacy contracts are stateless (and thus must be adopted to obtain citizenship); whether a gestational surrogate qualifies as a parent, despite no genetic relationship; conversely, whether genetics alone are sufficient to confer parenthood; whether paid surrogacy conducted abroad constitutes a criminal breach if such action is illegal at home; the extent to which a commissioning client may exert the right of reproductive choice on a paid surrogate (see the abortion example of "baby Gammy" herein); whether marital status is a relevant qualification for the commissioning client, and subsequently what provisions exist when marital status changes in mid-procedure (see the example of "baby Manjhi" herein); whether marital status is a relevant qualification for a potential surrogate; whether traditional (nongestational) surrogacy can be permitted in a commercial milieu, given its potential to further complicate definitions of legal parenthood; whether surrogates may have legal standing in any form on the child's birth certificate; and whether the conflict of interest manifest in a clinic acting on behalf of a client but performing medical procedures on a surrogate can be legally rectified.

\section{Case studies and examples}

A few famous cases have made international news, and have helped to frame some of the gaps in the local and global regulatory frameworks seeking to manage international surrogacy. The first landmark case was the 1987 birth of "baby M", who was the product of traditional (nongestational) surrogacy in the US. Mary Beth Whitehead had contracted with William and Elizabeth Stern to act as a surrogate mother for them. She was impregnated with an embryo (made by her egg fertilized with Stern's sperm). However, after delivering the baby, she sought to keep it as her own, in violation of the surrogate contract. The New Jersey Supreme Court ruled that "the government could not enforce a contract that orders a fit and loving mother to give away her child". ${ }^{46}$

In 2011, a similar case unfolded in the UK when a nongestational surrogate fought to keep the child she had birthed, claiming that she feared for its safety once she learned of the commissioning parents' violent tendencies. ${ }^{47}$ Surrogacy contracts are legal in the UK, but are not necessarily legally binding in court. Much like the case of M, family courts seek to rule in the perceived best interests of the child, regardless of the clarity of the written agreement between the surrogate and clients.

In 2001, Marla and Steve Culliton hired Mellissa Carroll as a gestational surrogate in Massachusetts. ${ }^{48}$ Despite Carroll not expressing any parental rights, the state court initially refused to add the genetic parents' names to the child's birth certificate, citing a tradition of only recognizing the woman who physically gives birth as the legal mother. The result was an eventual ruling that a gestational surrogate may enter into a binding agreement to forgo whatever parental rights she might have prior to the birth of the child, in contrast to the two cases described prior.

In 2008, the case of "baby Manjhi" made national news in India. A Japanese couple used a gestational surrogate with a donor egg, but then divorced before the baby was born. ${ }^{49}$ The wife (who was not genetically related to the baby) did not want the child, but the husband (who was genetically related to the baby) did. However, at the time, Japanese law did not recognize surrogacy, and Indian law would not allow a single man to adopt a child. The case underlined the extent to which adoption and parentage laws continue to be slow to adapt to the circumstances presented by the new paradigm of assisted reproduction.

In 2015, "baby Gammy" was produced when an Australian couple, David and Wendy Farnell, commissioned a surrogate named Pattaramon Janbua in Thailand. The baby was diagnosed with Down's syndrome, resulting in the couple not taking him back to Australia, even though his healthy twin sister was readily accepted. The international outcry was a primary reason for the subsequent changes in Thai surrogacy. ${ }^{38}$ The Farnells had asked Janbua to abort Gammy, but she had refused, citing her Buddhist antiabortion beliefs.

That case highlights some of the moral imperatives involved in navigating surrogacy. Did Janbua have a legal and moral right to choose for or against abortion, given that such a procedure would be performed on her body, but also given that the baby was not genetically (or legally) hers? And were the Farnells justified in abandoning their parental 
responsibilities to care for Gammy, since their request for an abortion was denied? The circumstances necessitate a values-based examination of the extent to which progeny become property, and who ultimately has decision-making power with respect to the child's interests.

The Gammy case was further complicated by revelations that David Farnell had been convicted and served prison time for child molestation. ${ }^{50}$ This raised questions about whether clients need specific qualifications before being permitted to enter into a surrogacy contract or any sort of ART program that will allow them to become parents. Since laws around surrogacy tend to be constructed atop an adoption base, the use of qualification standards derived from adoption regulations is a reflexive choice. In adoption cases, the state routinely vets putative parents for suitability, citing a variety of economic and lifestyle factors, including whether a criminal record exists. These same state-mandated qualifications are not applied to those creating families without ART, as everyone is legally free to reproduce, regardless of his or her circumstance. The larger moral and legal question becomes whether babies born via ART are more similar to natural births or to adoptions.

With respect to the medical challenges posed by surrogacy, an interesting case study was presented by Loike and Fischbach, ${ }^{51}$ who described a woman who was born with a kind of lymphoma that she had likely inherited from her mother and that her doctors feared would be transferred to her own children via her uterus. This is an example of maternal-fetal cell exchange, or microchimerism. The authors implied that the two-way nature of maternal-fetal exchange suggests that a surrogate carrying an embryo produced using this woman's genetic material would be at risk for infection. Moreover, her case presents the possibility for surrogates who are in otherwise good health to pass on undiagnosed genetic issues to fetuses to which they are not genetically related, via an infection path for which doctors presently do not test.

Other notable cases involve women serving as surrogates to give birth to their own grandchildren. ${ }^{8,52,53}$ These instances are interesting for their technological achievements and ethical and societal implications, though do not present challenges to any regulatory frameworks. A larger clinical risk concern emerges, though, when one considers the novel challenges of providing obstetric care for mothers who may be giving birth postmenopause.

\section{Prospects for policy recommendations}

$\mathrm{CBRC}$ in general, and international surrogacy in particular, must be understood as a global phenomenon requiring international frameworks and multinational data-collection paradigms. The European Union is taking a leadership role in exploring policy recommendations for managing international surrogacy among its member nations. ${ }^{54}$ However, since CBRC, and medical tourism in general, is a genuinely global phenomenon, any policy directives will fall short unless consideration is taken of the roles of nations beyond just member states. National or continental regulations are meaningless unless states are also prepared to pursue their citizens who transgress abroad, which seems an unlikely path, given that one of main drivers of the industry is clients seeking to bypass legal restrictions at home.

The single greatest barrier to the development of policy regarding international surrogacy is the profound lack of reliable data on the phenomenon's extent, distribution, and participants, even in well-resourced, well-monitored jurisdictions, such as the EU, where unlike other ART services there is no reporting standard for surrogacy, either nationally, internationally, or transnationally. ${ }^{54}$ The establishment of an international surveillance system, with appropriate controls for patient confidentiality, would be an enormous contribution welcomed by policy makers, clinicians, brokers, and users alike.

A further policy opportunity is the exploration of the extent to which surrogacy should resemble the adoption standard. The regulatory frameworks described in this paper depend upon the validity of surrogacy contracts, whereas intercountry adoption tends not to be based upon contract, but upon larger child-welfare statutes. The adoption standard is important, as it provides a model for voiding a previous parent-child relationship. In one view, that is precisely the nature of a surrogacy arrangement: the transfer of the surrogate's maternal relationship with the child to a relationship between child and client, necessitating the dissolution of the first relationship, but positive efforts need not be reserved for the legal class alone.

As Forman ${ }^{55}$ writes, "CBRC and the subsequent fragmentation of fertility treatment is likely to increase and doctors must be drivers for improvement of standards of reproductive medical care in the developing world, and elsewhere, as more countries and clinics seek to benefit economically from the expanding market in medical consumerism". This suggests that leadership must come from the clinical realm as well, and not necessarily just from the legal realm.

Where legislation fails, the adoption by clinics of ethical and transparency standards, especially surrounding the empowering of surrogate autonomy and negotiation power, can be a positive approach championed by clinicians 
independently of the state. ART clinics in India, for example, are currently expected to follow national guidelines, but are not yet subject to regulatory laws. Individual clinics can thus form "idiosyncratic policies regarding practice based on discretionary adherence to these guidelines with only the market and the management's sense of responsibility". ${ }^{56}$

The encouraging of a high ethical standard among clinics can result in an improved commercial profile among clients seeking a transaction with minimal ethical conflict. A quality standard, reflecting reduced risks to all agents, could be positioned as a competitive advantage and thus see wide adoption without the need for legal mandate. A related concept is Humbyrd's "fair trade surrogacy", ${ }^{27}$ which is a proposal for a mechanism not only to minimize harms to all parties, but most notably to ensure fair compensation to surrogates, reflective of global standards.

As with all complicated global health phenomena, progress on the management of risk associated with cross-border surrogacy begins with the collection of high-quality data. The industry is yet young, as are the regulatory measures seeking to manage it, as well as the types and extent of studies seeking to understand it. While much uncertainty surrounds the moral, medical, and legal disposition of the participants, it seems undeniable that the phenomenon is nonetheless poised for substantial global growth.

\section{Disclosure}

The author reports no conflicts of interest in this work.

\section{References}

1. Smerdon UR. Crossing bodies, crossing borders: international surrogacy between the United States and India. Cumberland Law Rev. 2008; 39(1):15-85.

2. Matorras R. Reproductive exile versus reproductive tourism. Hum Reprod. 2005;20(12):3571.

3. Inhorn MC, Patrizio P. Rethinking reproductive "tourism" as reproductive "exile". Fertil Steril. 2009;92(3):904-906.

4. Bhalla N, Thapliyal M. Foreigners are flocking to India to rent wombs and grow surrogate babies. 2013. Available from: http://www.businessinsider. com/india-surrogate-mother-industry-2013-9?IR=T. Accessed July 29, 2015.

5. Gugucheva M. Surrogacy in America. Cambridge (MA): Council for Responsible Genetics; 2010. Available from: http://www.councilforre sponsiblegenetics.org/pagedocuments/kaevej0a1m.pdf. Accessed July 29, 2015.

6. Cheung H. Surrogate babies: where can you have them, and is it legal? 2014. Available from: http://www.bbc.com/news/world-28679020. Accessed June 14, 2015.

7. Mohapatra S. Achieving reproductive justice in the international surrogacy market. Ann Health Law. 2012;21(1):190-210.

8. Sharma SD. Surrogacy - Blessing of Motherhood or Curse to Motherhood. Indian J Res. 2012;1(11):155-158.

9. Deonandan R, Loncar M, Rahman P, Omar S. Measuring reproductive tourism through an analysis of Indian ART clinic websites. Int J Gen Med. 2012;5:763-773.
10. Ethics Committee of American Society for Reproductive Medicine. Cross-border reproductive care: a committee opinion. Fertil Steril. 2013;100(3):645-650.

11. Meghani Z. A robust, particularist ethical assessment of medical tourism. Dev World Bioeth. 2011;11(1):16-29.

12. Helble M. The movement of patients across borders: challenges and opportunities for public health. Bull World Health Organ. 2011; 89(1):68-72.

13. Whittaker A. Cross-border assisted reproduction care in Asia: implications for access, equity and regulations. Reprod Health Matters. 2011;19(37):107-116.

14. Nygren K, Adamson D, Zegers-Hochschild F, de Mouzon J. Cross-border fertility care - International Committee Monitoring Assisted Reproductive Technologies global survey: 2006 data and estimates. Fertil Steril. 2010;94(1):e4-e10.

15. Hanefeld J, Smith R, Horsfall D, Lunt N. What do we know about medical tourism? A review of the literature with discussion of its implications for the UK National Health Service as an example of a public health care system. J Travel Med. 2014;21(6):410-417.

16. Rodino IS, Goedeke S, Nowoweiski S. Motivations and experiences of patients seeking cross-border reproductive care: the Australian and New Zealand context. Fertil Steril. 2014;102(5):1422-1431.

17. Spar D. Reproductive tourism and the regulatory map. N Engl J Med. 2005;352(6):531-533.

18. Johnston J. The ethics of outsourcing surrogate motherhood to India. Medscape J Med. 2008;10(3):52.

19. Lewin T. Coming to US for baby, and womb to carry it. 2014. Available from: http://www.nytimes.com/2014/07/06/us/foreign-couplesheading-to-america-for-surrogate-pregnancies.html?_r $=0$. Accessed July 29, 2015.

20. Deonandan R. An introduction to the ethical dimensions of reproductive medical tourism. In: Labonte R, Runnels V, Packer C, Deonandan R, editors. Travelling Well: Essays in Medical Tourism. Ottawa: Institute of Population Health, University of Ottawa; 2013.

21. Anand E, Singh J, Guha P, Kumar P. Blood, sweat, money and dummy tummies: surrogates in India. Poster presented at: 2015 IITGN Summer Institute on Global Health and Development; May 15-June 15, 2015; Ahmedabad, India.

22. Deonandan R. The public health implications of assisted reproductive technologies. Chronic Dis Can. 2010;30(4):119-124.

23. Deonandan R, Green $\mathrm{S}$, van Beinum A. Ethical concerns for maternal surrogacy and reproductive tourism. J Med Ethics. 2012;38(12): 742-745.

24. US Government. Prosecutorial Remedies and Other Tools to End the Exploitation of Children Today Act of 2003. 2003. Available from: http://www.gpo.gov/fdsys/pkg/PLAW-108publ21/html/PLAW-108 publ21.htm. Accessed July 29, 2015.

25. Assisted Human Reproduction Canada. The Assisted Human Reproduction Act: frequently asked questions. 2011. Available from: http:// archive.is/1UPVw. Accessed July 29, 2015.

26. Michigan Legislature. Surrogate Parenting Act (Act 199 of 1988). Lansing (MI): Michigan Legislative Council; 1988. Available from: http://www.legislature.mi.gov/(S(mrpy3perfdo0lhrew3oaafe3))/docu ments/mcl/pdf/mcl-act-199-of-1988.pdf. Accessed July 29, 2015.

27. Humbyrd C. Fair trade international surrogacy. Dev World Bioeth. 2009;9(3):111-118.

28. Deonandan R, Bente A. India's assisted reproduction bill and the maternal surrogacy industry. Int Rev Soc Sci Humanit. 2012;4(1):169-173.

29. Ramasubramanian H. United Kingdom High Court rules on commercial surrogacy contracts. 2010. Available from: http://blog.indiansurrogacy law.com/united-kingdom-high-court-rules-on-commercial-surrogacycontracts. Accessed July 29, 2015.

30. Deonandan R, Bente A. Assisted reproduction and cross-border maternal surrogacy regulations in selected nations. Br J Med Med Res. 2014;4(1):225-236.

31. Teman E. Birthing a Mother: The Surrogate Body and the Pregnant Self. Berkeley: University of California Press; 2010. 
32. Pandey AK, Inder D, Sharma N. Surrogacy and women's right to health in India: issues and perspective. Indian J Public Health. 2013;57(2):65-70.

33. Svitnev K. Legal regulation of assisted reproduction treatment in Russia. Reprod Biomed Online. 2010;20(7):892-894.

34. Aramesh K. Iran's experience with surrogate motherhood: an Islamic view and ethical concerns. J Med Ethics. 2009;35(5):320-322.

35. Suzuki K, Sawa R, Muto K, Kusuda S, Banno K, Yamagata Z. Risk perception of pregnancy promotes disapproval of gestational surrogacy: analysis of a nationally representative opinion survey in Japan. Int $J$ Fertil Steril. 2011;5(2):78-85.

36. Chamsi-Pasha H, Albar MA. Assisted reproductive technology: Islamic Sunni perspective. Hum Fertil (Camb). 2015;18(2):107-112.

37. Inhorn MC. Making Muslim babies: IVF and gamete donation in Sunni versus Shi'a Islam. Cult Med Psychiatry. 2006;30(4):427-450.

38. Australian Associated Press. Thailand bans commercial surrogacy. 2015. Available from: http://www.theguardian.com/world/2015/feb/20/ thailand-bans-commercial-surrogacy. Accessed July 29, 2015.

39. Farrell P. Baby Gammy, born into Thai surrogacy scandal, granted Australian citizenship. 2015. Available from: http://www.theguardian. com/australia-news/2015/jan/20/baby-gammy-born-into-thai-surrogacyscandal-granted-australian-citizenship. Accessed July 29, 2015.

40. Ministry of Health and Family Welfare, Government of India. The Assisted Reproductive Technologies (Regulation) Bill [draft]. 2010. Available from: http://icmr.nic.in/guide/ART\%20REGULATION\%20 Draft\%20Bill1.pdf. Accessed July 29, 2015.

41. Sama. The regulation of surrogacy in India: questions and complexities. 2011. Available from: https://samawomenshealth.wordpress. com/2011/04/23/the-regulation-of-surrogacy-in-india-questions-andcomplexities. Accessed July 29, 2015.

42. Shah C. Regulate technology, not lives: a critique of the draft ART (regulation) bill. Indian J Med Ethics. 2009;6(1):32-35.

43. Agence France-Presse. India bans gay foreign couples from surrogacy. 2013. Available from: http://www.telegraph.co.uk/news/worldnews/asia/ india/9811222/India-bans-gay-foreign-couples-from-surrogacy.html. Accessed July 29, 2015.

44. Ramasubramanian H. Assisted reproductive technology bill will be introduced in winter session of the Parliament? 2014. Available from: http://blog.indiansurrogacylaw.com/category/assisted-reproductivetechnology-bill. Accessed July 29, 2015.
45. European Union. Quality standards for human tissues and cells. 2004. Available from: http://eur-lex.europa.eu/legal-content/EN/ TXT/?uri=URISERV:c11573. Accessed July 29, 2015.

46. Blum L. Landmark fertility cases. Available from: http://abcnews. go.com $/$ Nightline/story $2 \mathrm{id}=128652 \&$ page $=1 \&$ singlePage $=$ true Accessed July 29, 2015.

47. Allen V, Ellicott C, Eccles L. 'I couldn't give my baby away ... they only wanted a toy': surrogate mother fought legal battle after learning that would-be parents were violent. 2011. Available from: http://www. dailymail.co.uk/news/article-1356176/Surrogate-mother-wins-casebaby-giving-birth.html. Accessed July 29, 2015.

48. Baillie H, McGeehan J, Garrett T. Health Care Law and Ethics. 6th ed. New York: Wolters Kluwer Law and Business; 2003.

49. Harmeet Shah Singh. Japanese girl born to Indian surrogate arrives home. 2008. Available from: http://edition.cnn.com/2008/WORLD/ asiapcf/11/02/india.baby. Accessed July 29, 2015.

50. Jabour B, Foster B. Child abuse convictions of Gammy's father prompt investigation. 2014. Available from: http://www.theguardian com/world/2014/aug/05/gammy-father-child-abuse-convictionsinvestigation. Accessed July 29, 2015.

51. Loike JD, Fischbach RL. New ethical horizons in gestational surrogacy. J Fertili In Vitro. 2013:1(2):1000109.

52. WMCActionNews5.com Staff. Woman serving as surrogate gives birth to second grandchild. 2014. Available from: http://www.wmcactionnews5.com/story/24651747/woman-serving-as-surrogate-gives-birthto-second-grandchild?hpt=us_bn8. Accessed July 29, 2015.

53. Daily Mail Online. Grandmother, 50, gives birth to grandchild after acting as daughter-in-law's surrogate for the second time. 2014. Available from: http://www.dailymail.co.uk/news/article-2554329/Grandmothergives-birth-grandchild-acting-daughter-laws-surrogate-second-time. html. Accessed July 29, 2015.

54. Brunet L, Carruthers J, Davaki K, King D, Marzo C, McCandless J. A Comparative Study on the Regime of Surrogacy in EU Member States. Brussels: European Parliament; 2013. Available from: http:/www. europarl.europa.eu/RegData/etudes/etudes/join/2013/474403/IPOLJURI_ET(2013)474403_EN.pdf. Accessed July 29, 2015.

55. Forman R. Cross-border reproductive care: a clinician's perspective. Reprod Biomed Online. 2011;23(7):808-810.

56. Vora K. Potential, risk, and return in transnational Indian gestational surrogacy. Curr Anthropol. 2013;54(S7):s97-s106.
Risk Management and Healthcare Policy

\section{Publish your work in this journal}

Risk Management and Healthcare Policy is an international, peerreviewed, open access journal focusing on all aspects of public health, policy, and preventative measures to promote good health and improve morbidity and mortality in the population. The journal welcomes submitted papers covering original research, basic science, clinical \& epidemio-

\section{Dovepress}

logical studies, reviews and evaluations, guidelines, expert opinion and commentary, case reports and extended reports. The manuscript management system is completely online and includes a very quick and fair peerreview system, which is all easy to use. Visit http://www.dovepress.com/ testimonials.php to read real quotes from published authors. 